\title{
The Others and My Image: Debate on Indigenous Representation with Martu and Pankararu Filmmakers
}

\author{
Renato Athias \\ Director of the Laboratory of Visual Anthropology, Federal University of Pernambuco \\ LAV-UFPE, Brazil.
}

etropic 14.2 (2015): 63-77. http://www.reefandleaf.com.au/etropic.html \& http://www.jcu.edu.au/etropic

\begin{abstract}
What interests us in this paper is to explore some issues related to the genre of documentary that we usually call the "ethnographic film" focused on the experience of two indigenous filmmakers on a residence project during the 5th International Ethnographic Film Festival of Recife (FIFER) in 2013. The Martu-Pankararu Project was an "exchange" programme between a filmmaker of the Martu people, from Central Australia, and a filmmaker of the Pankararu people, from the interior of Pernambuco in Brazil. The result of this activity is closely linked with the concept of representation used in the disciplinary field of visual anthropology.
\end{abstract}

\section{Field of Knowledge}

The field of knowledge of ethnographic film has traditionally been understood as one that uses language related to media imagery to describe and analyse a culture or a particular aspect of a culture. The productions of ethnographic films, or papers that articulate text with photographic images, are the main productions of this disciplinary field. These images are necessarily linked to the "other" and to those who are part of an audience, that is, to those who will see and will "receive" these images. The concept of representation is at the basis of these audiovisual productions of indigenous filmmakers, and certainly this concept was also a political operator for setting up the channel known initially as Indigenous Community Television (ICTV). This community channel was based on numerous local community experiences and ran until 2007 when it gave way to the channel known today as National Indigenous Television (NITV). Internationally, this is recognized as a unique project in Australia, based on experiences of the use of the image in the first person.

The reflections raised here are related to what we call "reception studies" (especially in the disciplinary field of media and communication studies), and are based on my experience as an organiser of the last five editions of the International Ethnographic Film Festival of Recife. The festival is held annually in the city of Recife, Brazil and includes a residency programme. 
The filmmakers, Curtis Taylor (Martu people, Australia) and Alexandre Pankararu (Pernambuco people, Brazil), who participated in the residence project during the 5th FIFER, met for the first time just two weeks before the festival in the Pankararu village in the mid hinterlands of the River São Francisco region of the state of Pernambuco. Their individual stories of making films on their social realities means they share a similar trajectory, which is shown through the images they produce. Indeed the social realities in which they live in are also similar. Their films and visual activities have a lot to do with the history of domination faced by indigenous communities in Brazil and Australia.

Indigenous representation is not something new. Indigenous populations have been present in film productions since the 1920s when Robert Flaherty discussed with the two Inuit protagonists, Allakariallak and Nuvalinga in the Canadian Arctic, the roles and development for his famous film Nanook of the North. ${ }^{1}$ It was perhaps in that instance that the notion of "shared anthropology" was born; a method that was to be further developed by Jean Rouch in the 1950s.

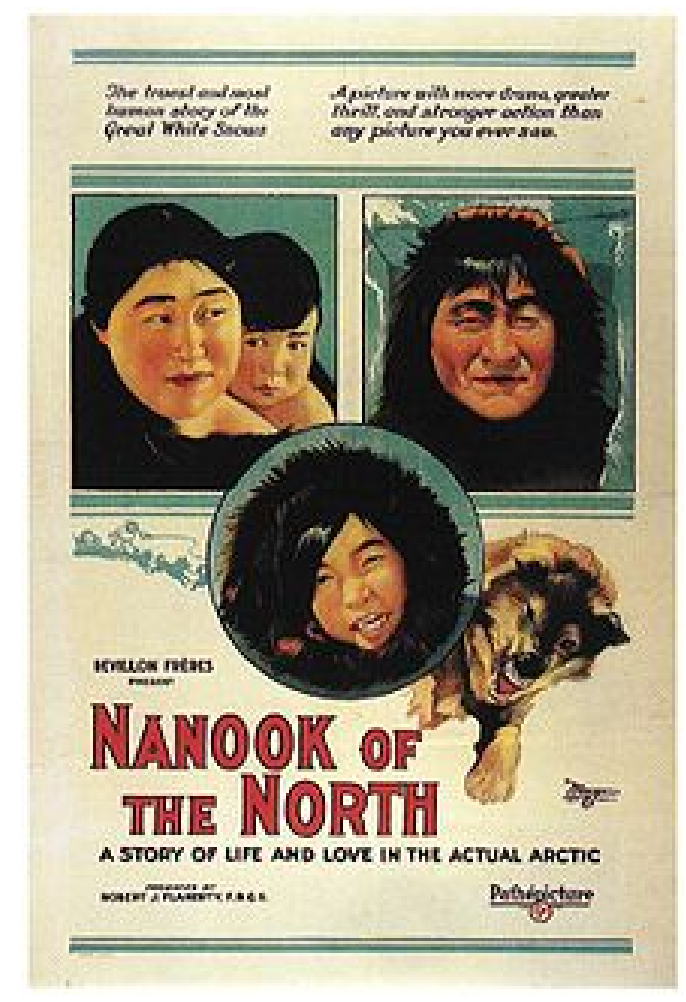

Image 1. 1922 Promotional Poster of the film Nanook of the North

\section{Ethnographical Film Festivals}

\footnotetext{
${ }^{1}$ In 1989, this film was one of the first 25 films to be selected for preservation in the United States National Film Registry by the Library of Congress as being "culturally, historically, or aesthetically significant".
} 
This documentary genre is at the root of the discussion initiated by André Leroi-Gourhan (1948), when he suggested a possible definition for the ethnographic or, as he calls it, ethnological film. To develop a possible definition, he classified the documentary films in three categories: 1. Research Films, "the Cinema of research is a means of" scientific recording; 2. Public Documentary, the film "where the exotic is present" and the film is a form of travel diary; and 3. The "specialized medium" movie (le film de milieu), conducted without a scientific intention, but that has ethnological value because of the way a story is told and thus surpasses the specialised means in which the film was made. There are many definitions for this genre but it is worth noting the definition by Timothy Asch (1973), in which he emphasises the ethnographic film as a teaching tool in anthropology. In this case we put in evidence that an ethnographic film situates itself precisely in reference to the depiction of a specific reality, to the description through the movements of a camera, and also to an important reflective element in the composition of the image narrative, which, for example, Dziga Vertov insisted on putting in his films (for instance Man with a Movie Camera, 1929).

In fact, specialists who work in this subdisciplinary field of anthropology note that these three categories together form what we call "ethnographic film". The ethnographic film is concerned primarily with social relations in the world, and there seems to be consensus around the idea that Robert Flaherty was one of the genre's pioneers, especially with Nanook of the North (1922) which allowed us to encounter the people of the Polar Regions. The genre experienced a revival in the late 1950s with the introduction of lightweight cameras of $16 \mathrm{~mm}$. During this period some filmmakers explored the technique of direct cinema, the most famous of them being Jean Rouch who is strongly associated with this "New Wave"2. But it is only in the late 1980s and early 1990s, with new digital technologies, that the field emerged as a much greater, specialist interest, in the genre of documentaries.

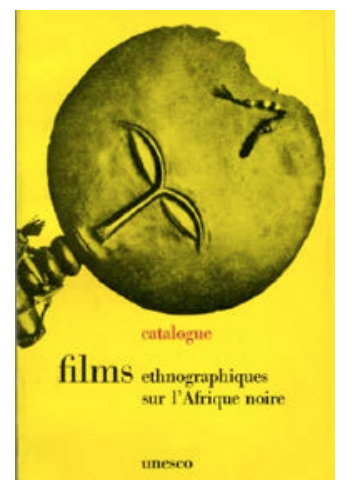

Image 2. The first and only ethnographic film catalogue on "Black Africa", produced by UNESCO. http://unesdoc.unesco.org/images/0000/000036/003622fo.pdf

As stated by Jean Rouch in an interview on the Bilan du Film Ethnographical and the viewing of ethnographic films:

\footnotetext{
${ }^{2}$ It is only in 1967, that UNESCO publishes the first and only ethnographic film catalogue on "Black Africa", giving greater emphasis to ethnographic movies.
} 
Au départ c'est André Leroi-Gourhan, le véritable créateur du film ethnographique, qui dès 1948, avait organisé une première confrontation des films ethnographiques. Plus récemment, il nous a semblé intéressant de faire suivre le Festival du Cinéma du Réel, qui se tient à Beaubourg et présente des films sociologiques et ethnographiques, par un "Bilan » où il serait possible de montrer des films qui n'avaient pas été sélectionnés car "trop ethnographiques", le "Cinéma du Réel" s'orientant en effet de plus en plus vers le cinéma documentaire. Ces deux manifestations sont donc complémentaires. (Rouch, 1986, p. 45) ${ }^{3}$

André Leroi-Gourhan is remembered as a pioneer in developing the discussion around the methodological aspects of ethnographic filmmaking, and in general all those who work with this documentary genre refer to his 'germinal' article on ethnological film (Freire, 2006). He recognised in the early Jean Rouch films an anthropological perspective on the debate around the "other" in films that gave a new importance to the moving image. These were conceived as the product of a long battle between the technical gesture and speech, and reflected profound transformations in techniques of expression.

In the 1950s, according to José Ribeiro da Silva (2007), ethnographic film became an institutional discipline, with experts recognised according to disciplinary criteria (Brigard, 1979). It is during this period that the first directors and their early films appear, notably: Jean Rouch, Les Maîtres Fous (1955), John Marshall, The Hunters (1958), Robert Gardner, Dead Birds (1964) and Tim Asch, The Feast (1969). Also during this period, the first training programmes were created, such as: the Comité du Film Ethnographique (founded in 1953 by Jean Rouch, Enrico Fulchignoni, Marcel Griaule, André Leroi-Gourhan, Henri Langlois and Claude Levi-Strauss, and hosted at the Musée de L'Homme), the Program in Ethnographic Film (PIEF, created in 1966 by Robert Gardner and Asen Balicki at Harvard University), and the Laboratoire de Audiovisuel en Sciences Religieuses (created by Jean Rouch, Claude Levi-Strauss and Germaine Dieterlen at the Ecole Pratique des Hautes Etudes in 1966).

Within this context of the rise of ethnographic film, it is appropriate to mention that Marc Piault (1995) explores a debate on the purpose of space and display time and what he calls the "break with the colonial cruise". Regarding the screening of ethnographic films in Europe up until the 1990s, Piault points out that:

\footnotetext{
${ }^{3}$ Translation: Initially it was André Leroi-Gourhan, considered by many the true creator of ethnographic film, who in 1948 organised the first competition of ethnographic film. More recently, it is interesting to follow the Cinema of the Real Festival held at Beaubourg, which presents sociological and ethnographic films by an appraisal list where it is possible to see the films that were not selected because they were "too ethnographic". The "Cinema of the Real" indeed orients itself increasingly towards documentary cinema. These two manifestations are therefore complementary. (Rouch, 1986)
} 
Il n'y avait plus de place pour un cinéma ethnologique qui aurait tenté de rendre compte de la dynamique et de l'autonomie d'une société autochtone en même temps que des modalités réelles du changement. La colonisation en état de marche ne pouvait accepter des images que dans la mesure où elles contribuaient à la justification de cette éventuelle transition de la sauvagerie ou de la simplicité primitives à l'instrumentalisation indigène. $\left(1995\right.$, p. 14) ${ }^{4}$

In the case of Brazil, and maybe in other countries as well, the 1980s saw more time and space offered to this type of production. In the history of anthropology, this is associated with a rising criticism towards anthropological studies linked to colonial attitudes. Faye Ginsburg strongly points out that:

o filme etnográfico na atualidade não pode pretender (assim como não pode mais a Antropologia em geral) ocupar a mesma posição no mundo que ocupou até mesmo vinte e cinco anos atrás [...]. O gênero faz parte agora de um inquietante leque de imagens provenientes de todo o planeta e de uma igualmente complexa diversidade de tecnologias para sua produção e circulação. $(1995, \text { p. } 74)^{5}$

It is precisely the festivals that place these sets of images of "otherness" in a certain time and space on screens, and share with multiple social groups a series of films and image narratives that show the "different" and enable people to view and confront themselves through these images that show the "other" and the "exotic".

The ethnographic film, as a documentary genre, has been present in the activities of Brazilian anthropologists for many years. The book edited by Bela Feldman-Bianco and Miriam Moreira Leite, Desafios da imagem: fotografia, iconografia e vídeo nas ciências sociais (Challenges of the Image: photography, iconography and video in the social sciences), highlights some important issues regarding the screening of ethnographic films. Of specific analytical interest is the text written by Patricia Monte-Mór, which explores some of the issues that I believe are specifically important to ethnographic film festivals. If we look at certain productions, we realize that some films produced in Brazil in the early twentieth century are already part of a significant number of films that we consider ethnographic. Here, as examples, I refer to the films produced and photographs taken by Major Reis for the Rondon Commission. These films, in many cases, are shown

\footnotetext{
${ }^{4}$ Translation: There was no place for an ethnological cinema that would have tried to explain the dynamics and autonomy of indigenous society together with real terms of change. Colonization could not accept images unless they contributed to the justification of a possible transition from savagery or primitive simplicity to the instrumentalization of natives. (Piault, 1995, p. 14)

${ }^{5}$ Translation: the ethnographic film today can not claim (as no longer can anthropology in general) to occupy the same position in the world it held even twenty-five years ago [...]. The genre is now part of a restless array of images from around the world and an equally complex range of technologies for their production and circulation. (Ginsburg, 1995, p. 74)]
} 
at certain festivals; while in other cases, some films use these images and sequences in current productions on indigenous peoples.

In Brazil, perhaps the oldest festival of ethnographic film has been the one organised by anthropologist Patricia Monte-Mór in Rio de Janeiro, since 1993. The International Exhibition of Ethnographic Film, as it is called, is a festival that highlights ethnographic production with a specific focus on diversity of cultures. The festival is not competitive, but is largely organised through the careful curating of national and international productions. The dialogue between Cinema and Anthropology is quite old, with numerous productions focusing on this relationship - a relationship that is well articulated by Claudine de France (1998).

It is important to emphasise that the main ethnographic film festivals emerged from the early 1990s, including, in Brazil, the aforementioned International Exhibition of Ethnographic Film in Rio de Janeiro; the Forum Doc in Belo Horizonte; the Mostra Amazonica in Manaus; and the International Ethnographic Film Festival in Recife, to name a few. Outside Brazil, also to name but a few, it is worth mentioning: the Margaret Mead Film and Video Festival in New York; the Festival Jean Rouch in Paris; the Ethnographic Festival of Nuoro, Sardinia; Contro-Sguardo in Perugia, Italy; the Göttingen International Ethnographic Film Festival in Germany; the Royal Anthropological Institute International Festival of Ethnographic Film in England; and the Delhi International Ethnographic Film Festival in India. This is a small sample of international festivals, there are others, but these are probably the most renowned for the high standard of production.

The ethnographic film or ethnographic cinema as documentary genre, particularly related to human populations in their aspects of sociability and cultural manifestations, comprises a wide range of interests spanning a huge variety of uses of the moving image. These productions shine a light on unknown documents and on the results of finished or ongoing research. The methods and techniques used in ethnographic cinema, according to my experience, are quite varied and are often associated with different theoretical traditions that can sometimes be perceived in the screening of a film. These productions support their image sequences in description, in what can be seen, or rather, in what the camera can pick up and show in a descriptive way. The images serve as "files" on a particular social group, and are often received and understood by an audience as "exotic", and, for the most part, outside an urban context - thus creating a sense of "strangeness".

Over the five years of the existence of the International Ethnographic Film Festival Recife (Festival Internacional do Filme Etnográfico do Recife - FIFER), it can be seen in the films shown that they, in general, have tried to describe different techniques, ways of life, art, livelihoods, rituals, ceremonies, and so on. And here, perhaps we can enter the first issue of this discussion about what the festivals of ethnographic films want to show through their selections to a wide audience - apart from the possibility of revealing other ways of living and other ways of seeing the world. In this regard, we agree with Marc Piault (1995) who sees ethnographic film festivals as spaces to break the "colonial view" of the other, and to allow this "view" to be shared with others. 
Analysing the films shown during FIFER, we note two broad categories of visual productions. Surely many other categories can be arranged to classify the hundreds of films that FIFER has screened in the last five years, but it is not useful for the purpose of this paper to extend the characterisation of these films beyond these two major groups in order to discuss the impact of the festival on a particular audience.

The first category of films, which represents the higher number of productions seen at FIFER festivals, relates to documentaries on the Amerindians, on traditional societies, indigenous peoples, on the "quilombolas", or on the Roma within the national borders of Latin America States. This category of film production is the biggest in terms of numbers of productions presented in festivals of ethnographic films in Brazil, and is, to date, the largest category of films entries in FIFER. For many, this group of films would fit into the definition of ethnographic film, since the "others" portrayed belong to other societies, different from the one to which we belong. In this case, a portion of the "exotic" is presented as a way to broaden the sense of "strangeness", and to serve as a mirror for situations that, in the context of Western societies, promotes this kind of festival.

This category can be divided into two subgroups, according to the film directors: firstly there are the films made by the indigenous filmmakers or "quilombolas" themselves, and secondly the films produced under a specific theme about indigenous peoples. Among these films the Festival has received a variety of productions. For instance, from movies "denouncing" unfair realities, to a very specific description of a particular ritual or traditional practice of a "quilombola”. However, what is noticed during these festivals, especially through the films that have won awards, is that the productions about indigenous peoples, where there was a large involvement of the indigenous community in the making of the film, were the movies that generated most interest. These films are the ones that receive larger audiences, and they tend to be a very interested audience. In this same category, the festival has received several films about indigenous peoples of other countries, which we felt was important in order to increase knowledge of this "otherness", outside the Brazilian context.

The second set of film productions observed in ethnographic film festivals, which is also very large, relates to aspects of the different "lifestyles" of Western society. These productions present "other" perspectives on everyday life. They often depict the relationship between people in social contexts of cities or communities inserted in different situations, usually portraying groups of people at risk and/or marginalised from society. These films generally present varied themes about the daily life of people, mainly in the urban context. These films also include documentaries involving social critique and a "denouncing" tone, especially in the ones relating to environmental issues. They employ many interviews and many stories. Some of these films manage to engage the audience very well with the subject presented; others carry out an exhaustive description of processes that are disappearing and that deserve to be documented.

What we realized over the course of the festivals of FIFER is that the public generally associates traditional peoples a lot more with the ethnographic aspect of film productions. This association has been noted as common across all the different audiences of the festival, both the audiences in the University, as well as the public that 
has no relation with the academic sphere and who attend screenings outside university related spaces. Marcius Freire (2006, p. 160), discussing documentary film, presents two possibilities by looking at the "language" of these productions. He discusses the distinction between a "scientific language" and a "literary description" very close to fiction. He believes that:

a distinção entre a descrição científica e a descrição literária não está,
portanto, no próprio texto, mas em um status que lhes é dado
independentemente dos fatos que as motivaram; e tal status lhes é atribuído
por fatores que lhes são exteriores: o lugar de fala do autor; a crítica
especializada; os especialistas em estudos literários, etc. (Freire, 2006, p. 160)

In other words, we can say that it is the relationship between director and audience that gives the possibility of "meaning" to the visual production, or enables the distinction between different uses of languages. The productions made by indigenous filmmakers themselves will be able to distinguish documentary from fiction, not only by the argument of authority (since the filmmakers are indigenous themselves), but also because they transmit the message in a direct, unmediated way. We will not enter in depth into this debate, but rather emphasise the fact that it is precisely this opposition between filmmaker and audience that is the strongest and most important in the various settings and audiences of an ethnographic film festival. It must be said that it is not the contact that is happening on the screen, nor in the sound of the film narrative, that reveals whether what you are watching is a fiction or a documentary. The representation of the people, the scenery, lighting and framing of a filmic sequence, edited by a director, will not provide the evidence that the visual record belongs to a historical world or a world created to be shot.

Faced with the issues that have been discussed, I think it is important to reiterate that the ethnographic film festivals collaborate effectively, as Marc Piault says, to break with the colonial discourse on the "other". The image is a strong tool and has great power over people to increase, above all, respect for others. These screening spaces are virtually the only way, and place in which, to watch these visual productions, because these films will certainly not be part of "mainstream" cinema or television. Even if they were to be publicly broadcast, this would mainly be outside of any major programme or schedule. Festivals stand as a space for respect by insisting that people should be seen primarily as part of an intercultural society in which the "ethnographed" or "exotic" others may also have a specific place, and especially participate as protagonists of their own demands. In the case of FIFER, over the past five years the festival has strongly reinforced this view. Even within institutions that help promote these festivals, FIFER has become an important place to discuss and understand the "other".

\footnotetext{
${ }^{6}$ Translation: the distinction between the scientific description and the literary description is therefore not in the text itself, but in a status that is given to them regardless of the facts behind them; and such status is assigned to them by factors external to them: the author's position; the specialized critics; the specialists in literary studies, etc. (Freire, 2006, p. 160)
} 


\section{Festival and Indigenous filmmakers}

Currently there are several festivals that seek to place in their programmes indigenous productions as a way to give more legitimacy to the range of productions that appear in these events. However, the "residence" experience in ethnographic film is less prominent. This was an innovation developed by FIFER and this experience deserves to be discussed. Here we are concerned with the relationship between the residential experience and the notion of representation. The residential activity involves indigenous filmmakers (a local and a foreigner) living for a period of time before the festival in the same village. The village thus receives the foreign director coming to participate in the festival and the period of residence is sufficient for the foreign director to gain perception of the situation of the local Pernambuco Indians.

It is important to emphasise that the social and economic context of the families and homes in which the the two filmmakers are housed are part of the same environmental feature, since in both cases they are situated in a semi-arid region with very similar characteristics and where water is the central element in the life of people who inhabit these regions. Moreover, in the case described here, both Alexandre Pankararu (Pernambuco people, Brazil) and Curtis Taylor (Martu people, Australia) come from locations in which they live in an intercultural context and deal with many prejudices and discrimination towards their communities and environment. This aspect allows the two filmmakers to gain a better understanding of the situation of indigenous peoples. Furthermore the indigenous representative coming from abroad (in this case Aboriginal Australia) can gain a clearer notion of indigenous peoples in Pernambuco, because the reality is 'experienced' and the director's participation in village activities will generate a large impact on the body of knowledge on indigenous peoples. It is no longer just about meeting and filmmaking. The knowledge produced is extremely important so that images can have a greater impact in the statements of those involved.

To bring indigenous filmmakers to ethnographic film festivals enables the possibility of sharing with these people concerns about reality, about the "real", as Jean Rouch used to say. Today, it is the indigenous filmmakers that present themselves, sharing first-person accounts of image narratives and productions of their knowledge about the ethnographic situations in which they live in different parts of the world. However, it is not about showing the "exotic", in fact these productions are far from portraying the other as exotic. Indeed the ethnographic film entries every year are much more committed to the reality and the interests of the people who are portrayed. Showing the "exotic" for the sake of "exotic" is out of this perspective and is not part of what we are call "shared anthropology". A text by David MacDougall from the nineties entitled The Visual in Anthropology (1997) gives an overview of how the "natives" were portrayed at fairs or exhibitions with the interest and goal to show the "view" of the author of the film and not the point of view of the native.

Clifford Geertz debates this issue in an article of the seventies (1974), where he seeks to discuss in which "point of view" lays the ethnographic description. His discussion on the status of "inside" and "outside" bears relevance to this discussion. In this specific case, 
Curtis and Alexandre could not be regarded as two people from "inside", rather, in this situation we also have an "outsider" and an "insider". What exists in common is the similarity of their political and social background, both in Australia and Brazil. Nevertheless, depending on the social space and time, one will always be "outside" and the other will be "inside".

The discussion at the cinema hall of the Joaquim Nabuco Foundation where the $5^{\text {th }}$ FIFER was held was very rich in issues on the notion of representation. The two indigenous film directors spoke in first person, both showing and describing what they saw. The images in the discussions were on the reality of domination and on the discourse about the inability to be "themselves". For this to happen, the two indigenous film makers in residence discussed the need to have more means to be able to express their own point of view.

The following photographic essay concludes this paper with an open invitation to further dialogue.

\section{Photo Essay}

“Curtis’ trip from Recife to indigenous Pankararu land lasted for about six hours. They arrived at night and Curtis was surprised the next morning to feel that the semi-arid climate and geography reminded him of his homeland. I soon noticed that we had a lot in common. The Pankararu people who met him were very curious to learn and know more about the Martu and the curiosity was mutual because Curtis also wanted to know more about the Pankararu. Curtis wanted to know everything about the lifestyle of the Pankararu People. During our conversations, despite the geographic distance, I felt that our communities had the same problems. That's why he understands very well our situation. This exchange generated tremendous empathy that seems to shine in these few selected photos for this article. It was not necessary to speak Australian English to understand what Curtis said. It was a very interesting to see how he engaged with people. I remember he talked for a long time with our leader Dona Hilda. The two got along together. I was amazed. I don't know in what language they were speaking! I only know that they understood each other very well. This fact impresses me, alongside his interest and his desire to understand our way of life. I hope he can come back soon and who knows one day I can also visit his land.” (Alexandre Pankararu) 


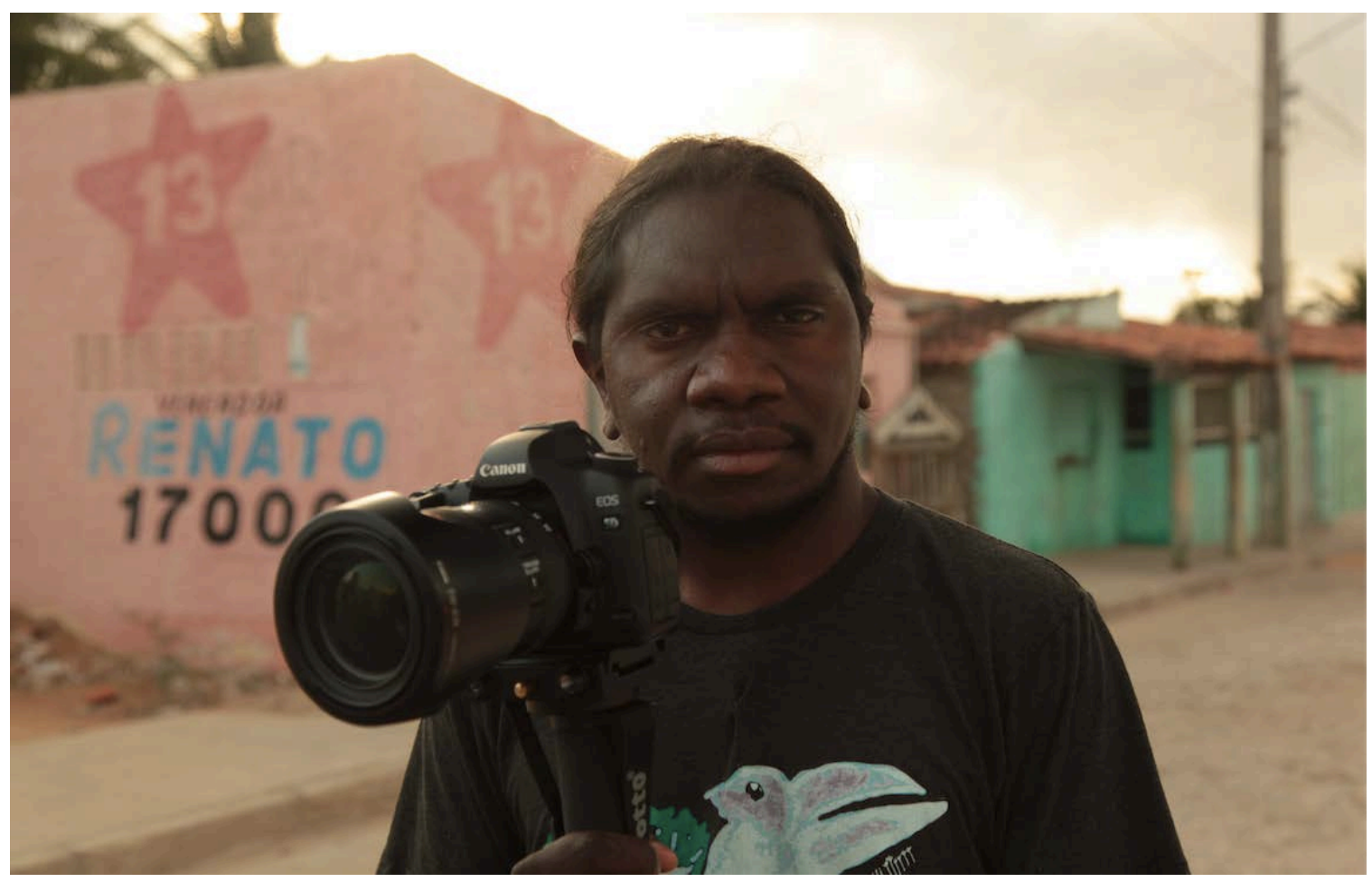

Curtis in one of the roads in Jatobá, Pankararu Land

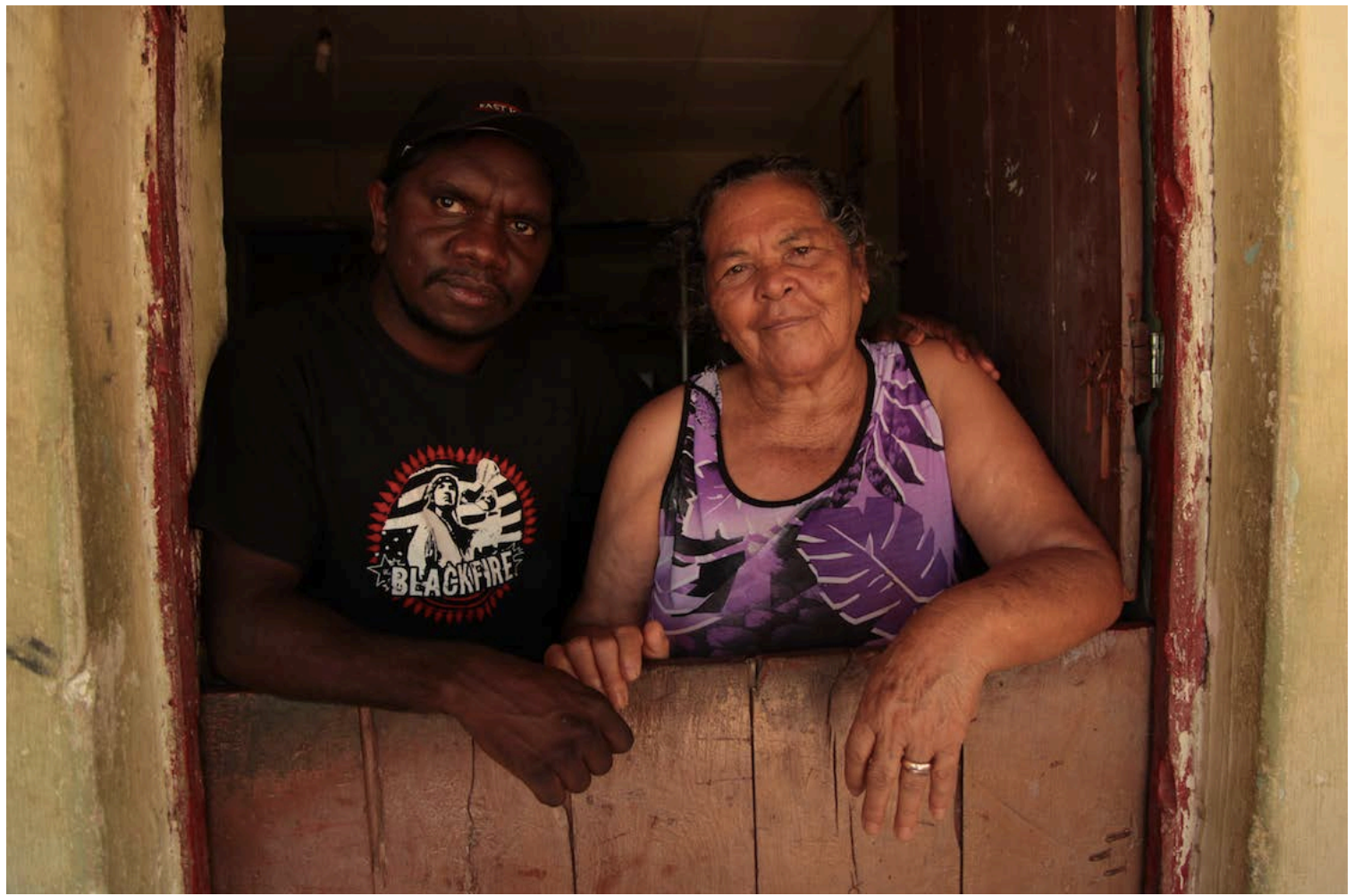

Curtis with Dona Hilda, leader of Serrinha in Pankararu Land 


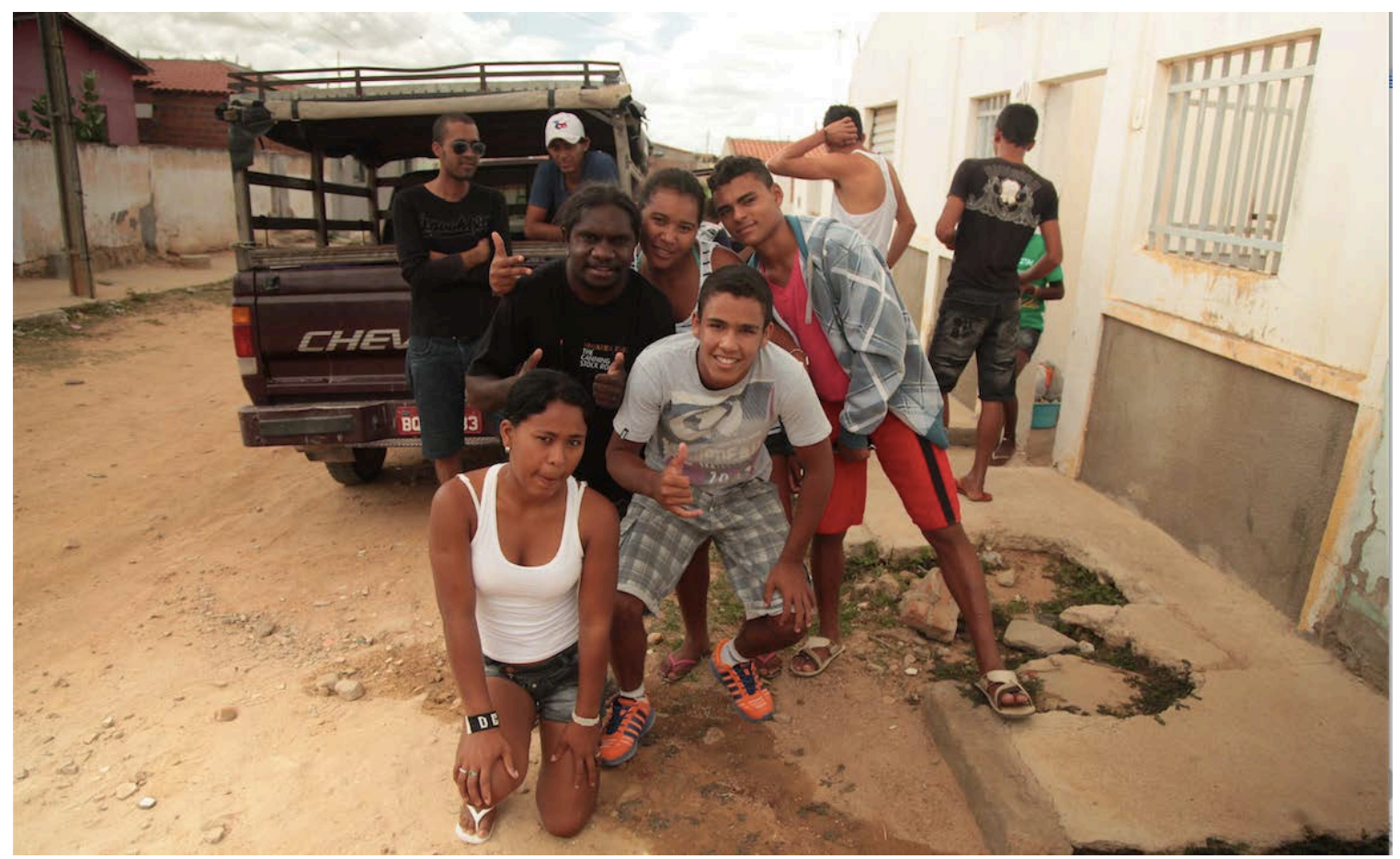

The young Pankararu follow Curtis in Pankararu Land

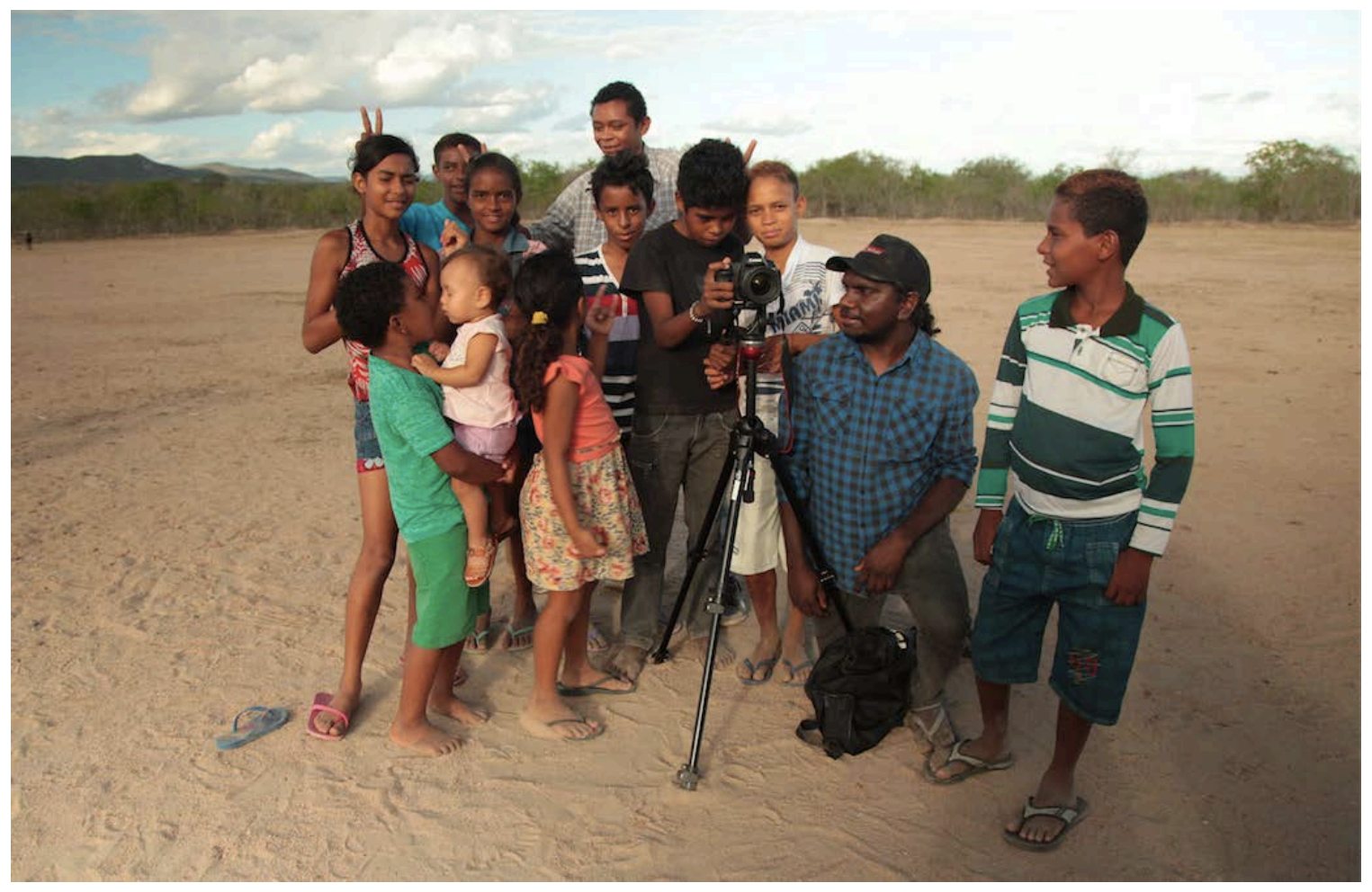

The young Pankararu follow Curtis in Pankararu Land 


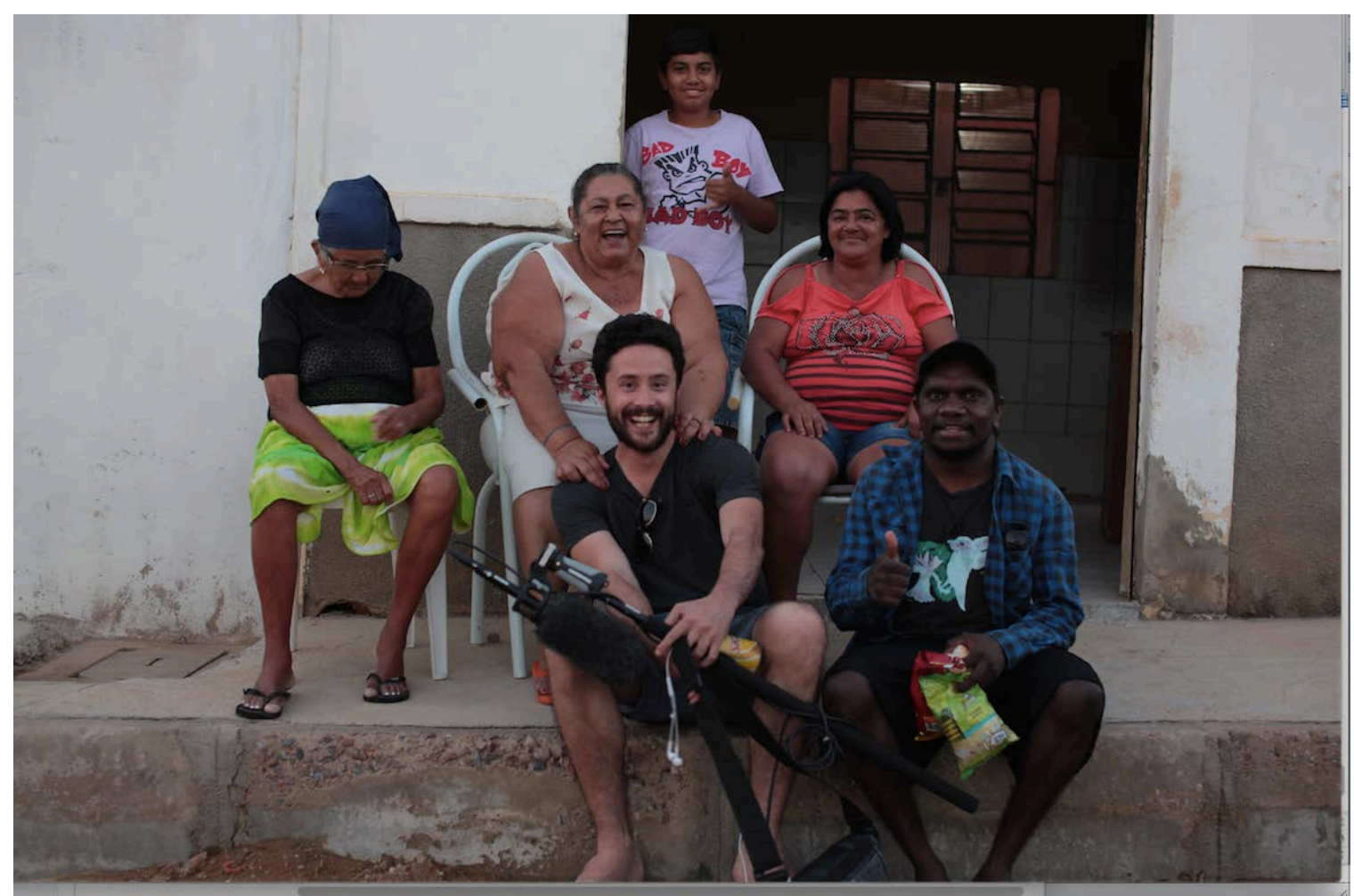

In front of the Alexandre's family house with Evan, a member of Curtis's team

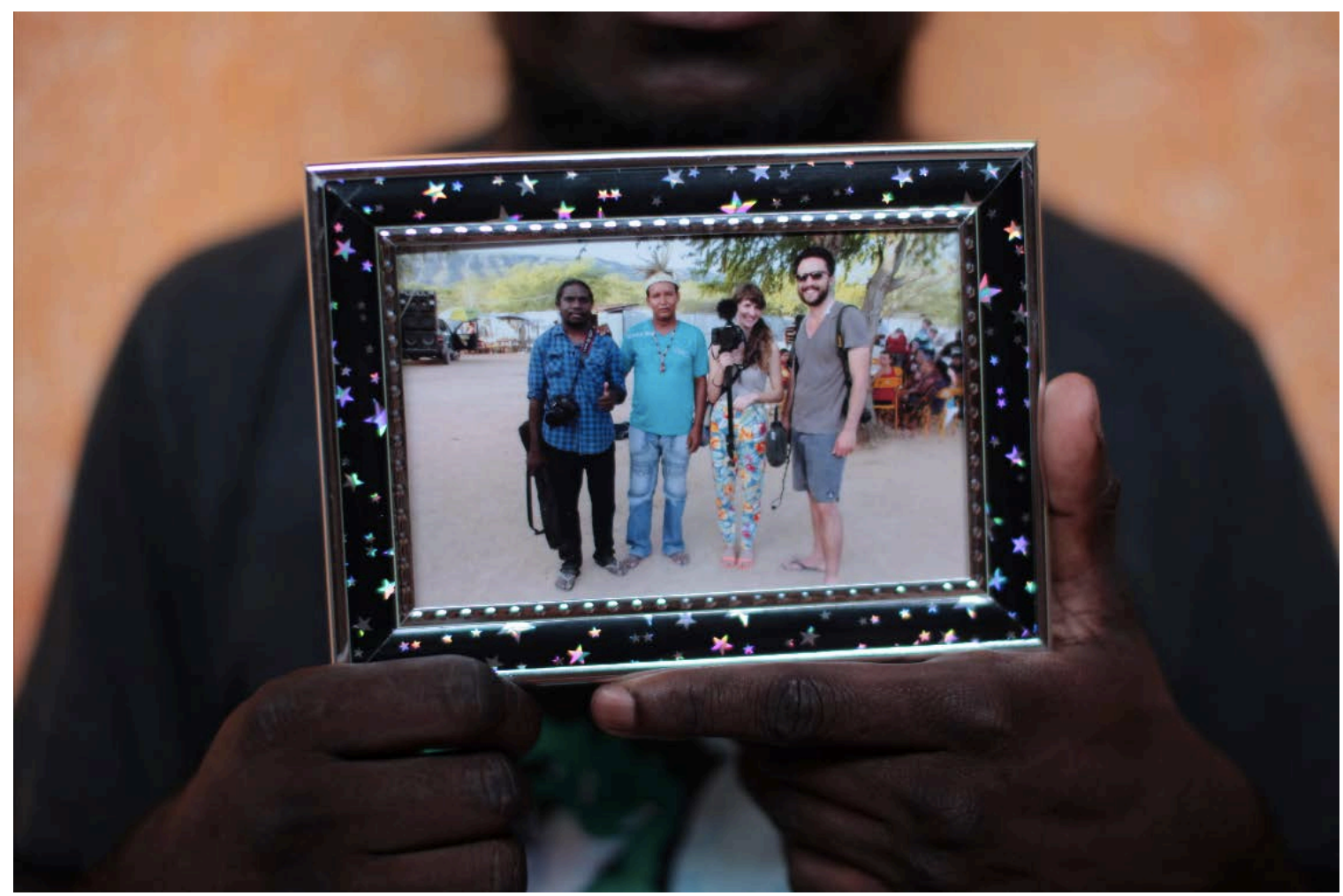

All photographs are from Caro Macdonald, Anthropologist and member of Curtis Taylor's team among the Pankararu. 


\section{Works Cited}

Alfonso, A. I., Kurti, L. \& Pink, S. (2004). Working Images: Visual Research and Representation in Ethnography. London: Routledge

Asch, T., Marshal, J. \& Spies, P. (1973). Ethnographic Film: Structure and Function. Annual Review of Anthropology, 2 (1), 179-187.

Caldarola, V. J. (1988). Imaging process as ethnographic inquiry. Visual Anthropology, 1 (4), 433-51.

Freire, M. (2006). Prolegômenos para um entendimento da descrição etnocinematográfica. Cadernos de Pós-Graduação, Campinas, Anno 8, 3 (3), 153168.

Geertz, C. (1974). From the native's point of view: on the nature of anthropological understanding. Bulletin of the american academy of arts and sciences, 28 (1), 2645.

Ginsburg, F. (1995). The parallax effect: The impact of aboriginal media on ethnographic film. Visual Anthropology Review, 11 (2), 64-76.

MacDougall, D. (1997). The Visual in Anthropology. In M. Banks \& H. Morphy (Eds). Rethinking Visual Anthropology (pp. 276-295). New Haven and London: Yale University Press.

Peixoto, C. (1996). Do diário de campo à câmera na mão ou de como virar antropólogo cineasta. Revista de Antropologia, 39 (2), 225-273.

Piault, M-H. (1995). L’Exotisme em le Cinéma Ethnographique: La Rupture d’Une Croisière Colonial. Horizontes Antropológicos, 1 (2), 11-22.

Pink, S. (2007). Doing Visual Ethnography: Images, Media and Representation in Research. London, UK: Sage.

Terrain (1986). Le Bilan du film ethnographique: entretien avec Jean Rouch. Terrain 7, Octobre

Worth, S. \& Adair, J. (1972). Through Navajo Eyes. Bloomington: Indiana University Press.

Worth, S. (1981). Studying Visual Communication. (Edited with Introduction by L. Gross). Philadelphia: University of Pennsylvania Press. 